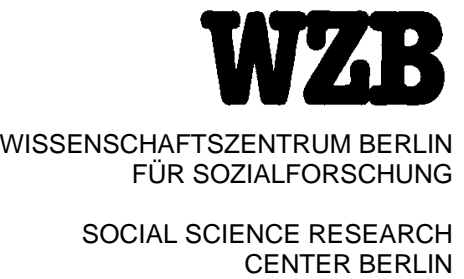

Alastair R. Beresford *

Dorothea Kübler **

Sören Preibusch *

\title{
Unwillingness to Pay for Privacy: \\ A Field Experiment
}

* University of Cambridge, UK

** WZB and Technical University Berlin

SP II $2010-03$

May 2010

(C) Copyright remains with the authors

Research Area

Markets and Politics

Research Unit

Market Behavior
Schwerpunkt II

Märkte und Politik

Abteilung

Verhalten auf Märkten 


\section{ABSTRACT}

\section{Unwillingness to Pay for Privacy: A Field Experiment *}

by Alastair R. Beresford, Dorothea Kübler ${ }^{\dagger}$ and Sören Preibusch

We measure willingness to pay for privacy in a field experiment. Participants were given the choice to buy a maximum of one DVD from one of two online stores. One store consistently required more sensitive personal data than the other, but otherwise the stores were identical. In one treatment, DVDs were one Euro cheaper at the store requesting more personal information, and almost all buyers chose the cheaper store. Surprisingly, in the second treatment when prices were identical, participants bought from both shops equally often.

Keywords: privacy, willingness to pay, field experiments

JEL Classification: C93, D12

ZUSAMMENFASSUNG

\section{Keine Zahlungsbereitschaft für Datenschutz: Ein Feldexperiment}

Wir messen die Zahlungsbereitschaft für Datenschutz in einem Feldexperiment. Die Teilnehmer konnten maximal eine DVD bei einem von zwei Online-Shops kaufen. Einer der beiden Läden verlangte immer mehr sensitive Daten als der andere, aber abgesehen davon waren die Läden gleich. Im ersten Treatment waren alle DVDs genau einen Euro günstiger bei dem Laden, der mehr sensitive Daten abfragte, und fast alle Käufer wählten diesen günstigeren Laden. In einem zweiten Treatment mit identischen Preisen bei beiden Läden kauften die Teilnehmer überraschenderweise bei beiden Läden gleich häufig.

Acknowledgements: We thank Wei Min Wang and Mark Henninger for very valuable research assistance. Financial support from the SFB649 ("Economic Risk") is gratefully acknowledged.

$\dagger \quad$ Corresponding author: Social Science Research Center Berlin (WZB), Reichpietschufer 50, D10785 Berlin, Germany. Email: kuebler@wzb.eu, tel: +49 3025491 440, fax: +49 3025491400. 


\title{
Unwillingness to Pay for Privacy: A Field Experiment*
}

\author{
Alastair R. Beresford, University of Cambridge, UK \\ Dorothea Kübler**, Social Science Research Center (WZB) and Technical University Berlin \\ Sören Preibusch, University of Cambridge, UK
}

\begin{abstract}
We measure willingness to pay for privacy in a field experiment. Participants were given the choice to buy a maximum of one DVD from one of two online stores. One store consistently required more sensitive personal data than the other, but otherwise the stores were identical. In one treatment, DVDs were one Euro cheaper at the store requesting more personal information, and almost all buyers chose the cheaper store. Surprisingly, in the second treatment when prices were identical, participants bought from both shops equally often.
\end{abstract}

Key words: privacy; willingness to pay; field experiments.

JEL Codes: C93, D12

*Acknowledgements: We thank Wei Min Wang and Mark Henninger for valuable research assistance. Financial support from the SFB649 ("Economic Risk") is gratefully acknowledged.

**Corresponding author: Social Science Research Center Berlin (WZB), Reichpietschufer 50, D-10785 Berlin, Germany, email: kuebler@wzb.eu, phone: +49 3025491 440, fax: +49 30 25491400. 


\section{Introduction}

The economics of privacy is controversial. The Chicago School (Posner, 1981) argues that privacy protection harms efficiency. In contrast, it has been asserted that property rights over the private data of individuals lead to the efficient outcome (Shapiro and Varian, 1997). But this view is contested, too. First, privacy may lead to efficient equilibrium outcomes even if people do not appreciate it individually (Hermalin and Katz, 2006; Wathieu 2009). Second, many contracts involving personal data are incomplete or highly opaque, as they typically lack clear-cut information about secondary uses and sharing of personal information, thereby limiting consumers' ability to understand what their data are used for, even retrospectively. Up to now, economists have not systematically studied choices regarding privacy in such environments.

It has been observed that consumers express concerns regarding misuse of personal data yet continue to provide personal data on social networks and online shopping sites. ${ }^{1}$ To understand this behavior, observations from a natural environment have the disadvantage that the (unobservable) cost of switching to another supplier affects choices. Relatedly, presentbiased preferences have been put forward as an explanation of inconsistent privacy choices (Acquisti, 2004). In our experiment, we are able to control for both explanations as there are two competing online stores that differ with respect to the mandatory data collected, and buying at the more privacy-friendly store does not prolong shopping time nor does it affect delivery time. ${ }^{2}$ Moreover, we do not draw attention to the issue of privacy as a whole (as in Tsai, 2007, where privacy ratings in search engines encourage consumers to choose more

\footnotetext{
${ }^{1}$ See for example Acquisti and Grossklags (2005).

${ }^{2}$ In an experiment by Berendt et al. (2005) with a monopoly online store, present-biased preferences are a potential source of observed privacy choices.
} 
privacy-friendly companies despite higher prices), but simply confront consumers with different data requirements at the two shops.

\section{Experimental design}

Participants were given the opportunity to buy one DVD from one of two online stores, named "SilverDisc Frankfurt" and "SilverDisc Cologne". SilverDisc is a multichannel retailer of DVDs selling through Amazon, its own online shop, and a local branch in Berlin. The two branches in Frankfurt and Cologne are fictitious, but were chosen (with consent from SilverDisc) to minimize any differences between the two stores. All personal data provided by participants were given to SilverDisc and to Amazon as part of the transaction to purchase the DVD; this was explained in the instructions. On the order form, participants ticked a box to confirm they agreed with the data protection regulations and general terms and conditions of SilverDisc and Amazon, which were available upon request from the experimenters.

A selection of DVDs was presented to the participants and listed on two order forms, one for “SilverDisc Frankfurt” and one for "SilverDisc Cologne”, that were presented side-by-side to minimize search costs. ${ }^{3}$ Participants were also free to search via a desktop computer for other DVDs and print new order forms. Two treatments were conducted. In both treatments, the mandatory data items for the two online shops were kept constant. While last name, first name, postal and email address were mandatory for both shops, "SilverDisc Frankfurt" also required a date of birth and monthly income, whereas "SilverDisc Cologne" asked for the year of birth and favorite color as mandatory fields. ${ }^{4}$ In treatment EQ, the prices at the two shops

\footnotetext{
${ }^{3}$ Instructions and order forms are posted on http://www.wzb.eu/mp/vam/publications/journals.de.htm.

${ }^{4}$ Neither Amazon nor SilverDisc ask for income and favorite color. Thus, these data items had not been provided before by subjects who had already shopped at the online stores ( $75 \%$ with Amazon and $11 \%$ with SilverDisc).
} 
were equal, whereas in treatment DIF all prices at "SilverDisc Frankfurt" were exactly one Euro less than the prices at "SilverDisc Cologne". Thus, in DIF there was a trade-off between data requirements and prices as subjects found information on personal income more sensitive than on favorite color (see Section 3).

After subjects had made their purchase decision, they were asked to answer a postexperimental questionnaire. Apart from some general questions, we asked participants how willing they are in general to provide personal data such as income and favorite color as well as other items. And we asked those who made a purchase how satisfied they were with the chosen store regarding privacy and price.

All 225 participants in the experiment (students from the Technical University Berlin) received a show-up fee of 6 Euros which they received regardless of whether they made a purchase. In addition, all orders were subsidized by a discount of 7 Euros. The quoted price on the order form corresponded to the Amazon.de retail price plus the Amazon.de shipping costs (3 Euros) minus 1 Euro for “SilverDisc Frankfurt” in treatment DIF.

\section{Results}

Of the 225 participants, 74 made a purchase..$^{5}$ Table 1 provides an overview of the results from both treatments DIF and EQ. In DIF, 39 of the 42 purchases were made at "SilverDisc Frankfurt” where prices were 1 Euro lower. Thus, participants predominantly chose the firm with the lower price and the more sensitive data requirement, indicating that they are willing to provide information about their monthly income and date of birth for a 1 Euro discount.

To establish a benchmark of privacy concerns in purchasing decisions, we conducted treatment EQ in which the two firms asked for the same price, but differed with respect to the

\footnotetext{
${ }^{5}$ Less than $9 \%$ of the non-buyers mentioned privacy concerns or lack of trust as the main reason for
} not buying while the majority indicated the product or its price. 
data items required for the transaction. In this treatment, approximately the same number of participants purchased a DVD at "SilverDisc Frankfurt" and "SilverDisc Cologne". Thus, the more privacy friendly firm failed to attract more customers even though prices were equal at both stores.

The results of treatment EQ are surprising given the preferences over mandatory data items provided by subjects in the post-experimental questionnaire (Table 2). In treatment DIF, the fact that 32 out of 39 participants shopped with Frankfurt but reported a lower willingness to report income (required by the Frankfurt branch) than favorite color (required by the Cologne branch) can be rationalized with the price difference. However in EQ, 8 of the 15 customers of Frankfurt said they were less happy providing the data required by Frankfurt than by Cologne (with 6 being neutral and 1 preferring to provide the data asked for by Frankfurt). ${ }^{6}$ In addition, we asked customers to rate their satisfaction with price and privacy policy of the chosen store (see Table 3). All Frankfurt buyers in EQ who responded to a question concerning satisfaction with the privacy practices of Frankfurt (13 of 15) were dissatisfied. ${ }^{7}$

The results can be explained if participants (mainly students) are unconcerned about privacy issues. However, in the post-experimental questionnaire $75 \%$ of the participants indicated that they have a very strong interest in data protection, and 95\% said that they are interested in the protection of their personal information. Thus, participants' concerns were slightly higher than those reported in the Eurobarometer Survey (Gallup, 2008).

\footnotetext{
${ }^{6}$ This is evidence against the hypothesis of private benefits or indifference when providing personal information, but collective costs in our setup (Wathieu 2009).

7 Table 3 also shows that participants noticed the difference in data requirements and prices between the two firms. Those who shopped with Cologne in treatment EQ were significantly more satisfied with the firm's privacy policy than those who shopped with Frankfurt. In treatment DIF, those shopping with Frankfurt were significantly happier with the prices than those shopping with Cologne.
} 
Providing false information is one method of protecting personal information. But except for one student who did not indicate his income, all subjects provided values that were reasonable in magnitude.

\section{Conclusion}

The experiment demonstrates an unwillingness to pay for privacy as the vast majority of subjects provide their monthly income for a price discount of one Euro. Even without a price discount, only half of the subjects shopped with the more privacy-friendly branch of the DVD retailer. This result is surprising given that most subjects who provide sensitive information are dissatisfied with it. Thus, observed behavior can neither be explained by a lack of awareness of privacy issues, nor can it be rationalized as a resolution of the trade-off between price and data protection in favor of price.

Two interpretations are possible: either the stated dissatisfaction with data collection and privacy protection can be regarded as uninformative as it is uncorrelated with choices, or behavior in the experiment is not in line with revealed-preference theory. In the latter case, the results shed doubt on the view that pure assignment of property rights in personal information is sufficient to achieve efficiency. 


\section{References}

Acquisti, A. (2004). Privacy in Electronic Commerce and the Economics of Immediate Gratification. Proceedings of the ACM Electronic Commerce Conference (ACM EC), ACM, p. 21-29.

Acquisti, A. and J. Grossklags (2005). Privacy and Rationality in Individual Decision Making. IEEE Security and Privacy, p. 24-30.

Berendt, B., Günther, O. and S. Spiekermann (2005). Privacy in E-Commerce: Stated Preferences vs. Actual Behavior. Communication of the ACM (CACM), vol. 48, no. 3.

Gallup Organization: Data Protection in the European Union - Citizens’ Perceptions (2008). Analytical Report. Flash Eurobarometer Series.

Hermalin, B. E. and M. L. Katz (2006). Privacy, Property Rights and Efficiency. Quantitative Marketing and Economics, 4, pp. 209-239.

Posner, R. A. (1981). The Economics of Privacy. American Economic Review, 71, pp. 40509.

Shapiro, C. and H. Varian (1997). US Government Information Policy, unpublished manuscript, University of California, Berkeley. 
Tsai, J., S. Egelman, L. Cranor and A. Acquisti (2007). The Effect of Online Privacy Information on Purchasing Behavior: An Experimental Study. Workshop on the Economics of Information Security (WEIS).

Wathieu, L. (2009). Privacy as Resistance to Segmentation. Mimeo. 


\section{TABLES}

Table 1. Number of purchases at the two stores per treatment.

\begin{tabular}{|l|l|l|}
\hline Treatment & $\begin{array}{l}\text { "SilverDisc Frankfurt" } \\
\text { (income/date of birth) }\end{array}$ & $\begin{array}{l}\text { "SilverDisc Cologne" } \\
\text { (favorite color/year of birth) }\end{array}$ \\
\hline DIF & 39 & 3 \\
\hline EQ & 15 & 17 \\
\hline
\end{tabular}

Table 2. Sensitivity of mandatory data items.

\begin{tabular}{|l|l|l|l|l|}
\hline \multicolumn{2}{|l|}{} & \multicolumn{2}{|l|}{\begin{tabular}{l}
\multicolumn{2}{l|}{ Less willing to provide } \\
information on
\end{tabular}} \\
\hline Treatment & Bought at & $\begin{array}{l}\text { Favourite } \\
\text { color }\end{array}$ & Income & Neutral \\
\hline DIF & Cologne & 0 & 3 & 0 \\
\hline & Frankfurt & 0 & 32 & 7 \\
\hline EQ & Cologne & 0 & 17 & 0 \\
\hline & Frankfurt & 1 & 8 & 6 \\
\hline
\end{tabular}

Note: This table reports on the answers to the question "When you are asked for data, how willing are you to provide the following items?” Income and favorite color were listed among a number of other items. 
Table 3. Absolute frequencies of satisfaction after purchase decision.

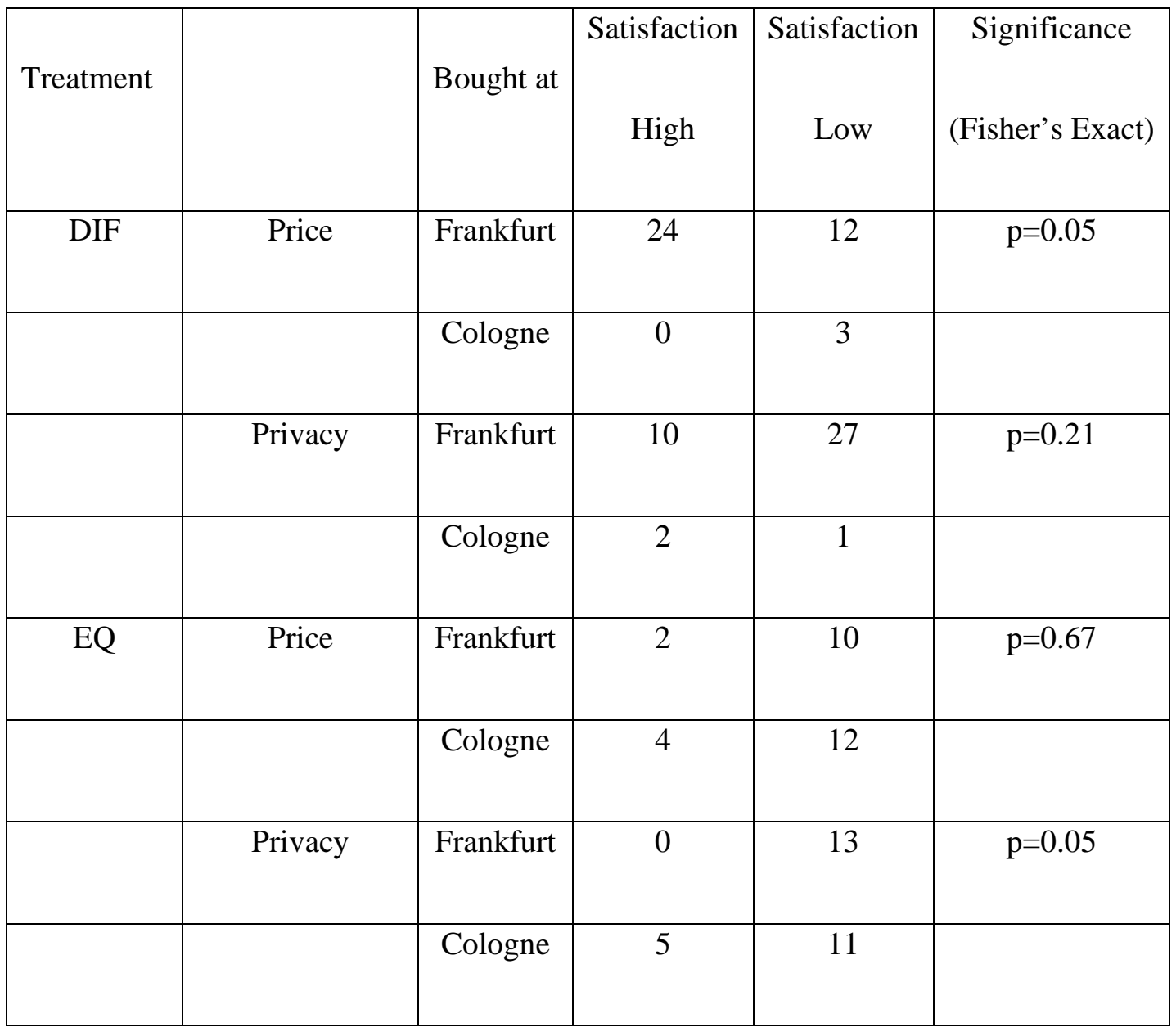

Note: This table reports on the answers to the question "How satisfied are you with the chosen store regarding price and privacy?” (Satisfaction values z-transformed; missing data for participants exactly between high and low; p-values two-tailed). 


\section{Your Order}

would like to order the free-delivery products marked below. will receive an additional $€ 7$ discount today from the given prices.

\begin{tabular}{|c|c|c|}
\hline (C) & Gran Torino & $€ 11,95$ \\
\hline (1) & Hannah Montana - Der Film & $€ 16,95$ \\
\hline 0 & 24 - Season 7 ( 6 DVDs) & $€ 43,95$ \\
\hline ○ & Ice Age 3: Die Dinosaurier sind los (\& Digital Copy) & $€ 9,95$ \\
\hline (C) & Illuminati & $€ 14,95$ \\
\hline (-) & Ice Age 1, 2 \& 3 (3 DVDs, inkl. Digital Copies) & $€ 21,95$ \\
\hline O & Stargate Atlantis - Season 5 & $€ 36,98$ \\
\hline 0 & David Garrett - David Garrett Live - In Concert \& in Private & $€ 18,95$ \\
\hline (0) & X-Men Origins: Wolverine (Extended Version inkl. Digital Cop & $€ 16,95$ \\
\hline (0) & Mamma Mial & $€ 9,95$ \\
\hline 0 & Stromberg - Die Bürographie (Stafel 1-3) & $€ 22,95$ \\
\hline (1) & Schöne Bescherung & $€ 9,95$ \\
\hline ○ & Selbst ist die Braut & $€ 19,98$ \\
\hline (1) & Star Wars - Trilogie, Episode V-VI (3 DVDs) & $€ 26,95$ \\
\hline ( & Australia & $€ 11,95$ \\
\hline 0 & Transformers 2 - Die Rache & $€ 16,95$ \\
\hline$\odot$ & Star Wars Trilogie: Der Anfang - Episode I-III & $€ 26,95$ \\
\hline 0 & Two and a Half Men: Mein cooler Onkel Charlie - Die komplet & $€ 11,97$ \\
\hline O & Terminator - Die Erlösung & $€ 10,97$ \\
\hline ○ & Nachts im Museum 2 (inkl. DVD mit Digital Copy) & $€ 16,95$ \\
\hline (6) & Marley \& Ich & $€ 11,95$ \\
\hline (1) & Stromberg - Staffel 4 & $€ 29,95$ \\
\hline 0 & Willkommen bei den Sch'tis & $€ 14,95$ \\
\hline 0 & Twilight - Bis(s) zum Morgengrauen (2 DVDs) & $€ 16,95$ \\
\hline (0) & Loriot - Voliständige Fernseh-Edition ((6 DVDs) inkl. 50 noch & $€ 31,95$ \\
\hline O & Star Trek & $€ 16,95$ \\
\hline O & Harry Potter und der Halbblutprinz (1 Disc) & $€ 14,97$ \\
\hline 0 & Slumdog Millionar & $€ 15,95$ \\
\hline ○ & Hangover & $€ 11,95$ \\
\hline 0 & Krabat (Einzel-DVD) & $€ 11,95$ \\
\hline
\end{tabular}

\section{Delivery Choices}

nine-day postal delivery

(1) four-day postal delivery (quick delivery)

For the quick delivery we need your identification details

Document: please choose- $-\square$ Number

at Gitt-wrapped (plus $€ 3$ )

\section{Your Details}

Required fields are marked with an asterisk

You can pay by direct debit or in cash to the experiment supervisor

\begin{tabular}{l}
\hline * Sex ( $\mathrm{m} / \mathrm{f})$ \\
* First name \\
* Surname \\
* Street, House number \\
* Postcode, City \\
* Email name (newly self-chosen) \\
* Telephone (mobile) \\
* Date of Bith \\
* Monthly salary \\
\hline Hobbies, Interests \\
Sort Code \\
Account number
\end{tabular}

$\square$ I agree with the Terms and Privacy Policy. *

I would like to subscribe to the SilverDisc Email Newsletter. 


\section{Your Order}

would like to order the free-delivery products marked below. will receive an additional $€ 7$ discount today from the given prices.

$\begin{array}{ll}\text { (0) Gran Torino } & € 12 \\ 0 \text { Hannah Montana - Der Film } & € \mathbf{1 7}\end{array}$

(1) 24 - Season 7 (6 DVDs) $€ 44,95$

(1) Ice Age 3: Die Dinosaurier sind los (\& Digital Copy) $€ 10,95$

(1) llluminati $€ 15,95$

(1) Ice Age 1, 2 \& 3 (3 DVDs, inkl. Digital Copies) $€ 22,95$

Stargate Atlantis - Season $5 \quad € 37,98$

(1) David Garrett - David Garrett Live - In Concert \& in Private $€ 19,95$

( X-Men Origins: Wolverine (Extended Version inkl. Digital Cop $€ 17,95$

(1) Mamma Mial $€ 10,95$

(-) Stromberg - Die Bürographie (Stafiel 1.3) $€ 23,95$

(-) Schöne Bescherung $€ 10,95$

(-) Selbst ist die Braut $\quad € 20,98$

(-) Star Wars - Trilogie, Episode IV-VI (3 DVDs) $€ 27,95$

- Australia $€ 12,95$

(1) Transformers 2- Die Rache $\quad € 17,95$

Star Wars Trilogie: Der Anfang - Episode H-III $€ 27,95$

(- Two and a Half Men: Mein cooler Onkel Charlie - Die komplet $€ 12,97$

- Terminator-Die Erlösung $€ 11,97$

(.) Nachts im Museum 2 (inkl. DVD mit Digital Copy) $\quad € 17,95$

() Marley \& Ich $€ 12,95$

() Stromberg - Staffel $4 \quad € 30,95$

- Willkommen bei den Sch'tis $\quad € 15,95$

Twilight - Bis(S) zum Morgengrauen (2 DVDs) $€ 17,95$

(C) Loriot - Vollständige Fernseh-Edition ( 6 DVDs) inkl. 50 noch $€ 32,95$

- Star Trek $€ 17,95$

(1) Harry Potter und der Halbblutprinz (1 Disc) $€ 15,97$

Slumdog Millionalr $€ 16,95$

(c) Hangover $€ 12,95$

Krabat (Einzel-DVD) $€ 12,95$

\section{Delivery Choices}

nine-day postal delivery
four-day postal delivery (quick delivery)
For the quick delivery we need your identification details:
Document: please choose - Number:
Gitt-wrapped (plus $€ 3$ )

\section{Your Details}

Required fields are marked with an asterisk.

You can pay by direct debit or in cash to the experiment supervisor

\begin{tabular}{ll|}
\hline * Sex (m/f) \\
* First name \\
* Surname \\
* Street, House number \\
* Postcode, City \\
\hline * Email name (newly self-chosen) \\
\hline Telephone (mobile) \\
\hline Year of Birth \\
\hline Favorite color \\
\hline Hobbies, Interests \\
\hline Sort Code \\
\hline Account number \\
\hline Account holder (name) \\
\hline
\end{tabular}

$\square$ I agree with the Terms and Privacy Policy. *

$\square$ I would like to subscribe to the SilverDisc Email Newsletter 


\section{Dear Participant,}

On behalf of the Technical University Berlin and the University of Cambridge, we welcome you. Please read the instructions carefully as they include important information about today's experiment.

Scientific background: You are taking part in a joint scientific experiment by the Technical University Berlin and the University of Cambridge. Experiments such as today's help us to collect reliable data that is needed for scientific publications and for academic journals. To analyze how consumers make decisions in increasingly competitive markets we will be giving out order forms from two branches of SilverDisc in Cologne and Frankfurt, who sell their products on Amazon.de.

Experiment length: We anticipate that the experiment will take 40 minutes.

Ordering and Buying: During today's experiment you will have the possibility to buy the product of your choice from one of the two firms of your choice. The range of products is the same for both firms. You are not obligated to buy. You can also decide not to buy anything.

Product range: The order form that you will soon be given represents only a small choice of available DVDs. During the experiment you can search for as many other film titles as you wish. All available products will then be shown and you can request a new order form for these products from one of the experiment supervisors.

Once you have decided to buy a product, your order will be placed. At Amazon.de, your order will be processed and confirmed and a new customer account will be created for you for that purpose. This account will be deactivated in four weeks once the return service agreement expires. A customer account will also be created by SilverDisc. The branch you have chosen and Amazon will then process your personal data.

Price and Payment: Payment for your chosen product takes place once you have chosen your type of payment. All prices are presented on the order form and can depend on which firm you have ordered from. Delivery is free of charge.

Remuneration and Attendance Allowance: If you buy one of the products on offer you will receive $a € 7$ subsidy. This subsidy will then be deducted from the purchasing price. Therefore, you will pay $€ 7$ less of the price given on the order form regardless of which product you buy or from which firm. You will not be given a subsidy should you choose not to purchase a product. 
Your attendance allowance of $€ 6$ will be paid in cash following the experiment. In total, today's remuneration can amount to $€ 13$.

Rules and Regulations: Take note that mobile telephones are not permitted during today's experiment. Please place all mobile phones or similar devices in your pocket or bag before the session begins.

Please remain seated during the course of the experiment, even if you conclude the experiment earlier than expected.

\section{Today's experiment consists of three stages:}

Preparation: You will be given an instruction form from the experiment supervisor. At the same time you will receive two printed order forms and an overview with background information on the film titles listed. The computer at your station will guide you through the experiment. It should, however, be switched off at the present time.

Please take a moment to check that you have all the necessary material. Inform the experiment supervisor if anything is missing. Otherwise you can begin reading through.

Purchasing: After the preparation, all participants simultaneously have the chance to complete one purchase and buy a maximum of one DVD. We then request that you confirm your decision on the screen. You do not need to wait but can then continue shopping should you wish to do so. Your remuneration today is not dependent on the speed of your decision.

When buying you can decide between one of the following three possibilities: (1) Purchase one of your selected products from SilverDisc Cologne; (2) Purchase one of your selected products from SilverDisc Frankfurt; (3) No purchase. If you don't choose any of those options you will not be entitled to remuneration. Should you opt for products that are not listed on the order form you can search your computer for more titles. The experiment supervisor will then give you a new order form with your favoured titles.

Ordering: Once you have chosen the product you wish to buy, the order form from the firm you have selected will be shown on your monitor. Please fill out the formula online. The printed order forms are a copy of the online forms and are only for your reference. After completing the order form online, your order is legally binding.

Payment: The experiment is completed once all participants have filled out the completion questionnaire. You will then be paid for taking part in the experiment. If you choose to pay in cash, please give us the final invoice amount shown on your screen. Both firms also offer payment by bank transfer. Under University Regulations, we ask you to save your original receipts for our records. 
Thank you for taking part. On behalf of the Technical University Berlin and the University of Cambridge we thank you once again for taking part in today's experiment, for reading through and for your compliance with the instructions. This study has been approved by the Ethics Committee of the University of Cambridge. Should you have any further questions please raise your hand and one of the supervisors will attend to you. If you are ready to start, then please confirm on your monitor that the experiment can now begin.

Prof. Dr. Dorothea Kübler

Technical University Berlin

Department of Economics

Straße des 17. Juni 135

D-10623 Berlin
Sören Preibusch

University of Cambridge

Computer Laboratory

15 JJ Thomson Avenue

Cambridge CB3 OFD

Please fill out the following Declaration of Consent for our files:

I understand that my participation is voluntary and that I may cancel at any time without giving reasons. I have read the above description of the research and declare my consent to participate.

Name:

Date:

Signature: 
Bücher des Schwerpunkts Märkte und Politik

Books of the Research Area Markets and Politics

Kai A. Konrad, Tim Lohse (Eds.)

Einnahmen- und Steuerpolitik in Europa:

Herausforderungen und Chancen

2009, Peter Lang Verlag

Kai A. Konrad

Strategy and Dynamics in Contests

2009, Oxford University Press

Roger D. Congleton, Arye L. Hillman, Kai A. Konrad

(Eds.)

40 Years of Research on Rent Seeking

2008, Springer

Kai A. Konrad, Beate Jochimsen (Eds.)

Föderalismuskommission II:

Neuordnung von Autonomie und Verantwortung

2008, Peter Lang Verlag

Mark Gradstein, Kai A. Konrad (Eds.)

Institutions and Norms in Economic Development

2007, MIT Press

Johannes Münster

Mobbers, Robbers, and Warriors

2007, Shaker Verlag

Kai A. Konrad, Beate Jochimsen (Eds.)

Der Föderalstaat nach dem Berlin-Urteil

2007, Peter Lang Verlag

Kai A. Konrad, Beate Jochimsen (Eds.)

Finanzkrise im Bundesstaat

2006, Peter Lang Verlag

Robert Nuscheler

On Competition and Regulation in Health Care

Systems

2005, Peter Lang Verlag

Pablo Beramendi

Decentralization and Income Inequality

2003, Madrid: Juan March Institute

Thomas R. Cusack

A National Challenge at the Local Level: Citizens, Elites and Institutions in Reunified Germany 2003, Ashgate

Sebastian Kessing

Essays on Employment Protection

2003, Freie Universität Berlin

http://www.diss.fu-berlin.de/2003/202

Daniel Krähmer

On Learning and Information in Markets and

Organizations

2003, Shaker Verlag

Tomaso Duso

The Political Economy of the Regulatory Process:

An Empirical Approach

Humboldt-University Dissertation, 2002, Berlin, http://edoc.hu-berlin.de/dissertationen/duso-tomaso2002-07-17/PDF/Duso.pdf
Bob Hancké

Large Firms and Institutional Change. Industrial Renewal and Economic Restructuring in France 2002, Oxford University Press

Andreas Stephan

Essays on the Contribution of Public Infrastructure to Private: Production and its Political Economy

2002, dissertation.de

Peter A. Hall, David Soskice (Eds.)

Varieties of Capitalism

2001, Oxford University Press

Hans Mewis

Essays on Herd Behavior and Strategic Delegation

2001, Shaker Verlag

Andreas Moerke

Organisationslernen über Netzwerke - Die

personellen Verflechtungen von Führungsgremien japanischer Aktiengesellschaften

2001, Deutscher Universitäts-Verlag

Silke Neubauer

Multimarket Contact and Organizational Design

2001, Deutscher Universitäts-Verlag

Lars-Hendrik Röller, Christian Wey (Eds.)

Die Soziale Marktwirtschaft in der neuen

Weltwirtschaft, WZB Jahrbuch 2001

2001, edition sigma

Michael Tröge

Competition in Credit Markets: A Theoretic

Analysis

2001, Deutscher Universitäts-Verlag

Torben Iversen, Jonas Pontusson, David Soskice

(Eds.)

Unions, Employers, and Central Banks

2000, Cambridge University Press

Tobias Miarka

Financial Intermediation and Deregulation:

A Critical Analysis of Japanese Bank-Firm-

Relationships

2000, Physica-Verlag

Rita Zobel

Beschäftigungsveränderungen und organisationales Lernen in japanischen

Industriengesellschaften

2000, Humboldt-Universität zu Berlin

http://dochost.rz.hu-berlin.de/dissertationen/zobel-rita2000-06-19

Jos Jansen

Essays on Incentives in Regulation and Innovation 2000, Tilburg University 


\section{DISCUSSION PAPERS 2008}

Dan Kovenock Brian Roberson

Dan Kovenock Brian Roberson

Vito Tanzi

Kai A. Konrad Kjell Erik Lommerud

Benny Geys Jan Vermeir

Benny Geys Jan Vermeir

Kai A. Konrad Dan Kovenock

Johannes Münster

Kai A. Konrad Dan Kovenock

Kai A. Konrad

Florian Morath

Joseph Clougherty

Anming Zhang

Jonathan Beck

Susanne Prantl

Jo Seldeslachts

Tomaso Duso

Enrico Pennings

Dan Kovenock Brian Roberson

Joseph Clougherty

Tomaso Duso

Benny Geys

Wim Moesen

Benny Geys

Friedrich Heinemann

Alexander Kalb

Johannes Münster

Benny Geys

Wim Moesen
Inefficient Redistribution and Inefficient

Redistributive Politics

Coalitional Colonel Blotto Games with Application to the Economics of Alliances

The Future of Fiscal Federalism

Love and Taxes - and Matching Institutions

Party Cues and Yardstick Voting

The Political Cost of Taxation:

New Evidence from German Popularity Ratings

The Alliance Formation Puzzle and Capacity

Constraints

Repeated Contests with Asymmetric Information

Competition for FDI with Vintage Investment and

Agglomeration Advantages

Non-binding Minimum Taxes May Foster Tax Competition

Strategic Information Acquisition and the Mitigation of Global Warming

Domestic Rivalry and Export Performance: Theory and Evidence from International Airline Markets

Diderot's Rule

The Role of Policies Supporting New Firms:

An Evaluation for Germany after Reunification

On the Stability of Research Joint Ventures: Implications for Collusion

Is the $\mathbf{5 0 - S t a t e}$ Strategy Optimal?

The Impact of Horizontal Mergers on Rivals:

Gains to Being Left Outside a Merger

Exploring Sources of Local Government Technical Inefficiency: Evidence from Flemish Municipalities

Local Governments in the Wake of Demographic Change: Evidence from German Municipalities

\section{Group Contest Success Functions}

Measuring Local Government Technical (In)efficiency: An Application and Comparison of FDH, DEA and Econometric Approaches
SP || $2008-16$

SP || $2008-01$

SP || $2008-02$

SP || $2008-03$

SP II $2008-04$

SP II $2008-05$

SP II 2008- 06

SP || 2008- 07

SP II $2008-08$

SP II $2008-09$

SP || $2008-10$

SP || $2008-11$

SP || $2008-12$

SP || $2008-13$

SP || 2008 - 14

SP || $2008-15$

SP || $2008-17$

SP || 2008- 18

SP II $2008-19$

SP II $2008-20$

SP II $2008-21$ 


\section{Áron Kiss \\ Benny Geys \\ Friedrich Heinemann \\ Alexander Kalb \\ Salmai Qari \\ Kai A. Konrad \\ Benny Geys \\ Kai A. Konrad Salmai Qari \\ Sven Chojnacki \\ Nils Metternich Johannes Münster \\ Oliver Gürtler Johannes Münster \\ Dan Kovenock Brian Roberson \\ Subhasish M. Chowdhury \\ Dan Kovenock Roman M. Sheremeta \\ Michael R. Baye Dan Kovenock Casper G. de Vries \\ Florian Morath Johannes Münster \\ Benny Geys}

Paolo Buccirossi

Lorenzo Ciari

Tomaso Duso

Giancarlo Spagnolo

Cristiana Vitale

Pedro P. Barros Joseph Clougherty

Jo Seldeslachts

Paolo Buccirossi Lorenzo Ciari Tomaso Duso Giancarlo Spagnolo Cristiana Vitale

Paolo Buccirossi Lorenzo Ciari Tomaso Duso Giancarlo Spagnolo Cristiana Vitale
Coalition Politics and Accountability

Voter Involvement, Fiscal Autonomy and Public Sector Efficiency: Evidence from German Municipalities

Patriotism, Taxation and International Mobility

The Last Refuge of a Scoundrel? Patriotism and Tax Compliance

Mercenaries in Civil Wars, $1950-2000$

Sabotage in Dynamic Tournaments

Non-Partisan 'Get-Out-the-Vote' Efforts and Policy Outcomes

An Experimental Investigation of Colonel Blotto Games

Contests with Rank-Order Spillovers

Information Acquisition in Conflicts

Wars, Presidents and Popularity: The Political Cost(s) of War Re-examined

Competition policy and productivity growth: An empirical assessment

How to Measure the Deterrence Effects of Merger Policy: Frequency or Composition?

Deterrence in Competition Law

Measuring the deterrence properties of competition policy: the Competition Policy Indexes
SP II $2009-14$

SP II $2009-01$

SP II $2009-02$

SP II $2009-03$

SP II 2009-04

SP || $2009-05$

SP II 2009-06

SP II 2009- 07

SP || $2009-08$

SP II $2009-09$

SP II $2009-10$

SP I| $2009-11$

SP || $2009-12$

SP || $2009-13$

SP II $2009-15$ 
Talat Mahmood The Decision to Migrate: A Simultaneous Decision Klaus Schömann

\section{Making Approach}




\section{DISCUSSION PAPERS 2010}

Dorothea Kübler Experimental Practices in Economics:

Dietmar Fehr Information and Beliefs in a Repeated Dorothea Kübler David Danz

Alastair R. Beresford Dorothea Kübler Sören Preibusch Performativity and the Creation of Phenomena

SP || $2010-01$

SP II $2010-02$ Normal-form Game

Unwillingness to Pay for Privacy: A Field Experiment
SPII $2010-03$ 
Bei Ihren Bestellungen von WZB-Papers schicken

Sie bitte unbedingt einen an Sie adressierten Auf-

kleber mit sowie je paper eine Briefmarke im Wert

von 0,51 Euro oder einen "Coupon Reponse Inter-

national " (für Besteller aus dem Ausland)
Please send a self addressed label and postage stamps in the amount of 0.51 Euro or a "CouponReponse International" (if you are ordering from outside Germany) for each WZB-paper requested

\section{Absender / Return Address:}

Wissenschaftszentrum Berlin

für Sozialforschung

Presse- und Informationsreferat

Reichpietschufer 50

D-10785 Berlin-Tiergarten

Hiermit bestelle ich folgende(s) Discussion paper(s):

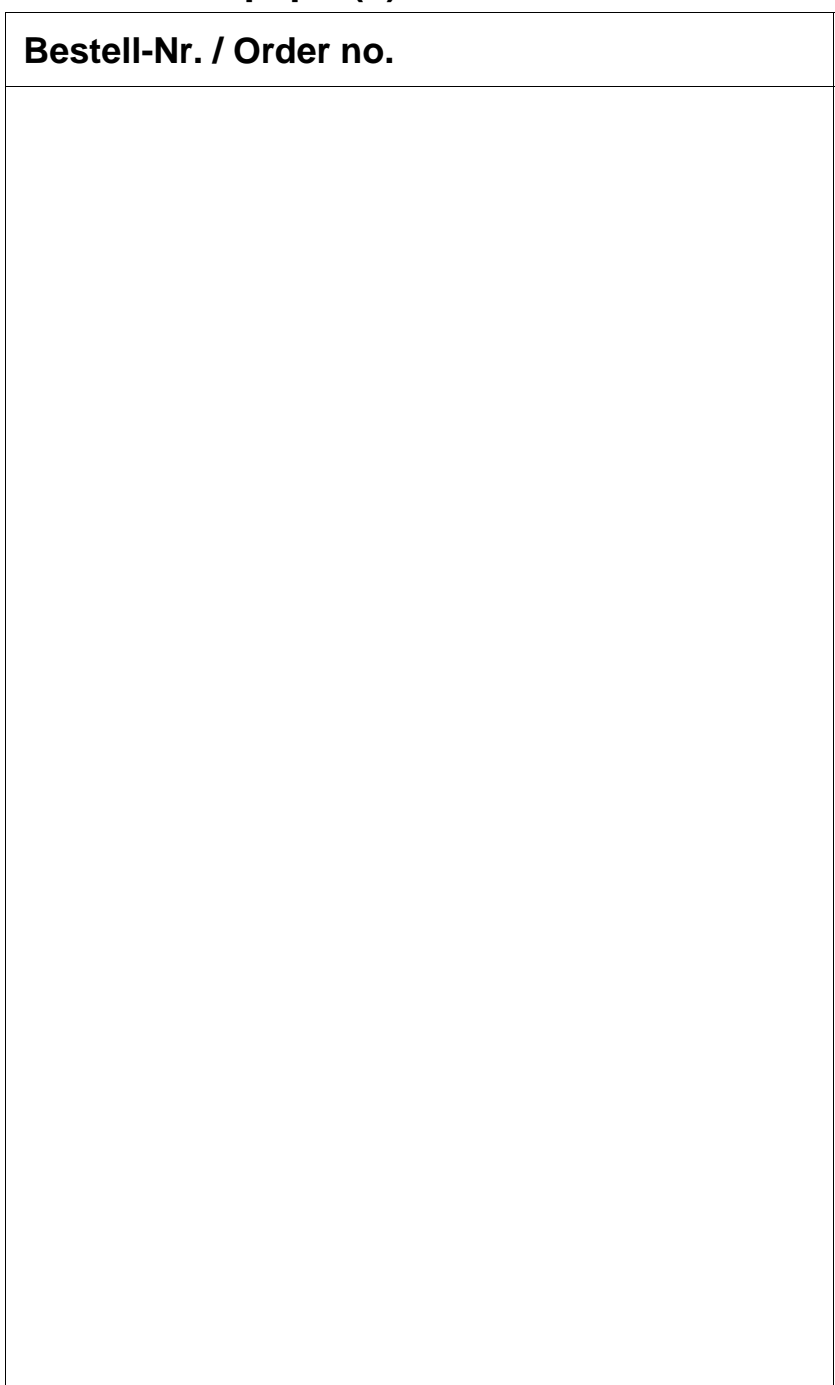

Please send me the following Discussion paper(s):

\section{Autor/in, Kurztitel /Author(s) / Title(s) in brief}

